\section{Gender and schooling inequalities in risk and protective factors for chronic diseases among Brazilian adults, through telephone survey}

\author{
Desigualdades de sexo e \\ escolaridade em fatores de risco \\ e proteção para doenças crônicas \\ em adultos brasileiros, por meio de \\ inquéritos telefônicos
}

\section{Deborah Carvalho Malta' \\ Erly Catarina Moura " \\ Otaliba Libanio de Morais Neto III}

' Coordenação Geral de Doenças e Agravos Não-transmissíveis; Departamento de Análise de Situação de Saúde, Secretaria de Vigilância em Saúde do Ministério da Saúde, Brasil; Escola de Enfermagem da Universidade Federal de Minas Gerais (UFMG). Belo Horizonte (MG), Brasil

" Núcleo de Pesquisas Epidemiológicas em Nutrição e Saúde da Universidade de São Paulo (NUPENS/USP) - São Paulo (SP), Brasil

II' Coordenação Geral de Doenças e Agravos Não-transmissíveis, Departamento de Análise de Situação de Saúde, Secretaria de Vigilância em Saúde do

Ministério da Saúde, Brasil; Universidade Federal de Goiás - Goiânia (GO), Brasil

\section{Resumo}

Objetivos: Analisar os fatores de risco e proteção para doenças crônicas não-transmissíveis (DCNT) e identificar as desigualdades sociais na sua distribuição entre adultos brasileiros. Métodos: Os dados utilizados foram coletados em 2007, por meio do VIGITEL, inquérito telefônico contínuo, em todas as capitais dos estados do Brasil, tendo sido analisadas pouco mais de 54.000 entrevistas. Foi calculada a razão de prevalência ajustada por idade, e as tendências em diversos níveis de escolaridade foram calculadas utilizando a regressão de Poisson com modelos lineares. Resultados: Foram descritas diferenças na prevalência de fatores de risco e proteção para DCNT, por sexo e escolaridade. Entre homens, as prevalências do excesso de peso, consumo de carnes com gordura aparente e dislipidemia foram maiores na faixa de maior escolaridade, enquanto o uso do tabaco, estilo de vida sedentário e hipertensão arterial foram menores. Entre as mulheres, o uso do tabaco, excesso de peso, obesidade, hipertensão e diabetes foram menores na faixa de maior escolaridade. $\mathrm{O}$ consumo de carnes com gorduras visíveis e estilos de vida sedentários foram maiores na faixa de maior escolaridade. Quanto aos fatores de proteção, o consumo de frutas e verduras e atividade física aumentaram em homens e mulheres com o aumento da escolaridade. Conclusão: Sexo e escolaridade exercem influência nos fatores de risco e proteção para DCNT, com valores mais desfavoráveis para os homens. O VIGITEL é uma ferramenta importante no monitoramento destes fatores junto à população brasileira.

Palavras-chave: doença crônica; fatores de risco; desigualdades; escolaridade; tabaco; atividade física. 


\section{Abstract}

Objectives: To assess risk and protective factors for chronic noncommunicable diseases (CNCD) and to identify social inequalities in their distribution among Brazilian adults. Methods: The data used were collected in 2007 through VIGITEL, an ongoing population-based telephone survey. This surveillance system was implemented in all of the Brazilian State capitals, over 54,000 interviews were analyzed. Age-adjusted prevalence ratios for trends at different schooling levels were calculated using Poisson regression with linear models. Results: These analyses have shown differences in the prevalence of risk and protective factors for CNCD by gender and schooling. Among men, the prevalence ratios of overweight, consumption of meat with visible fat, and dyslipidemia were higher among men with more schooling, while tobacco use, sedentary lifestyle, and high-blood pressure were lower. Among women, tobacco use, overweight, obesity, high-blood pressure and diabetes were lower among men with more schooling, and consumption of meat with visible fat and sedentary lifestyles were higher. As for protective factors, fruit and vegetables intake and physical activity were higher in both men and women with more schooling. Conclusion: Gender and schooling influence on risk and protective factors for CNCD, being the values less favorable for men. VIGITEL is a useful tool for monitoring these factors amongst the Brazilian population.

Keywords: chronic disease, risk factors; inequalities; educational status; tobacco; physical activity.

\section{Introduction}

The estimates from the World Health Organization (WHO) indicate that chronic noncommunicable diseases (CNCD) already account for $58.5 \%$ of all deaths worldwide and $45 \%$ of all global disease burden ${ }^{1}$. In Brazil CNCD account for $62.8 \%$ of all deaths by known causes ${ }^{2}$. Historical series of mortality statistics available for Brazilian state capitals indicate that the proportion of CNCD deaths has more than tripled between the 1930s and the 1990s ${ }^{3}$.

Global estimates show that a small set of risk factors accounts for the great majority of CNCD deaths and for quite a large proportion of CNCD disease burden. These factors include tobacco use, alcohol abuse, obesity, excess consumption of saturated fat (causing dyslipidemia), inadequate fruit and vegetable intake, and physical inactivity ${ }^{1}$. Studies have pointed out that the most effective mechanisms for reducing people's vulnerability to these "new epidemics" are those that promote healthy lives, acting for disease prevention and health promotion ${ }^{4}$.

Social inequalities determine the worst health indicators among low-income populations; it is not a result of a natural phenomenon, but rather of a malign combination of deficient, unequal and socially unfair policies and programs, poor policy management, iniquity in funding distribution, and other social determinants ${ }^{5}$. Health iniquities have been associated with health and social policies, causing inequality in morbidity/mortality and service access. An important question to be answered is whether health determinants equally impact all social groups $^{6,7}$.

According to the $\mathrm{WHO}$, the CNCD increase also greatly affects low-income people due to their greater vulnerability, lesser access to health services, greater exposure to risks, lesser access to healthy choices, i.e., lesser access to a healthy diet, lesser access to healthy spaces and environments, reducing the opportunities of promotion and prevention ${ }^{4}$.

Chronic disease and risk factor monitoring becomes important in view of public policies 
supporting promotion and prevention. As part of a process of providing effective instruments to monitor the frequency and distribution of the main CNCD determinants, the Brazilian Ministry of Health implemented, in 2006, the VIGITEL System - a surveillance system of risk and protective factors for chronic non-communicable disease telephone survey. This system is intended for continuous monitoring of the frequency and distribution of risk and protective factors for CNCD in all 26 state capitals, and the Federal District through telephone interviews ${ }^{8,9}$.

The distribution of risk and protective factors, according to gender and schooling, found through VIGITEL survey, is presented here with the purpose of identifying potential inequalities in their distribution.

\section{Materials and methods}

\section{Sampling}

The sampling procedures of the VIGITEL System allowed the obtainment of probabilistic samples of the adult population living in households with at least one landline telephone in each of the 26 state capitals and the Federal District in the study year.

The system established a minimum sample size of 2,000 individuals aged 18 years and older in each of the cities, in order to estimate the frequency of any risk factor in the adult population, with a $95 \%$ confidence coefficient and a maximum error of about $2 \%^{10}$.

At the first stage, the VIGITEL System systematically drew 5,000 phone lines in each city. These drawings, stratified according to city area or phone number prefix, were conducted from an electronic registry provided by the city's phone service provider. The lines drawn in each city were then re-drawn and divided into 25 sub-samples of 200 lines each, reproducing the same proportion of telephone lines from the area or phone number prefix. The sub-samples were created due to the difficulty in estimating beforehand the proportion of lines in the registry, which would be eligible for the system (active residential landlines), and therefore the total of lines to be drawn to reach 2,000 interviews.

In the second stage, VIGITEL was operated in parallel with the interviews including first the identification, among phone lines drawn, of those eligible for the survey, i.e., active residential phone lines. Commercial and out-of-service lines, besides the ones that did not answer after six calls made at different days, including Saturdays and Sundays and different times of the day (including night time), probably indicating empty houses, were excluded. In 2007, in the set of 27 cities, based on the telephone registry of the three telephone service providers that serve all 27 cities, the VIGITEL System drew 138,600 phone lines distributed in 693 sub-samples, and 75,876 eligible lines were identified. For each eligible line, after obtaining the user's agreement to participate in the survey, we proceeded to number those aged 18 years-old and older living in the household and then an adult individual was drawn to be interviewed. The calls made to 75,876 eligible lines resulted in 54,251 complete interviews with a response rate (interviews conducted/eligible for the interview of telephone lines drawn) of $71.5 \%$, ranging between $64.0 \%$ in Porto Alegre and 74.7 in Belo Horizonte ${ }^{6}$.

The refusal rate (refused interviews/ eligible for interview of telephone lines drawn), either at the first contact with the household or after the drawing to select the individual to be interviewed, was $4.8 \%$, ranging between $1.8 \%$ in Palmas and $11 \%$ in Rio de Janeiro.

\section{Data collection}

Telephone interviews were conducted by a vendor hired by the Brazilian Ministry of Health, from July to December 2007. The interview team, consisting on 60 interviewers, 4 supervisors and 1 coordinator, received prior training and was continuously supervised during the system's operation by one of the authors. The VIGITEL System questionnaire was designed to allow computer- 
assisted telephone interviews, i.e., interviews with questions directly read from a monitor screen and answers promptly electronically recorded.

This system also performs automatic random selection of the household's family member to be interviewed, automatic skipping ofnonapplicable questions based on previous answers, immediate prompting of missing information and interview duration, besides offering direct and continuous input to its database.

The VIGITEL questions (short and quick approach) collected information about: demographic and socioeconomic characteristics of the individual (age, gender, marital status, ethnicity, schooling, number of people, rooms, adults, and phone lines in the household); diet and physical activity associated with the CNCD development (for instance, frequency of fruit and vegetable and saturated fat intake, frequency and duration of physical activity and television watching); self-reported weight and height; tobacco and alcohol consumption; and selfreported health status and previous medical diagnosis of high-blood pressure, diabetes, and high cholesterol.

The system's questionnaire was created based on several models of simplified questionnaires for CNCD risk and protective factor monitoring systems ${ }^{11,12}$, and the expertise acquired with the testing system in São Paulo and other four Brazilian capital cities $^{13}$. In 2007, the median duration of interviews performed using the VIGITEL System was 8.5 minutes.

\section{Data analysis}

VIGITEL System estimates (and related 95\% confidence interval) are herein presented stratified by gender and schooling for selected risk and protective factors for CNCD. The estimates are provided for the sample of adult population living in 27 Brazilian capitals.

The selection of risk and protective factors for chronic diseases was based on their importance in determining the overall disease burden, which was estimated by the WHO in
Latin America ${ }^{14}$. Thus, they included: tobacco use (proportion of smokers, regardless of frequency and intensity of smoking); alcohol abuse (proportion of individuals consuming, in one of the last 30 days, more than four (women) or five (men) shots of alcoholic beverages); overweight (proportion of individuals with bodymassindex(BMI)equals to or greater than $25 \mathrm{~kg} / \mathrm{m}^{2}$ ); consumption of meat with visible fat (proportion of individuals usually consuming red meat or chicken without removing the skin and visible fat); sedentary lifestyle (proportion of individuals who, in the last three months, did not engage in any kind of leisure-time physical activities, did not perform any intense physical efforts at work, did not walk or did not ride a bicycle to work, and did not do any "heavy" household cleaning); and high-blood pressure, diabetes and dyslipidemia reported, based on previous medical diagnosis.

The protective factors included: adequate leisure-time physical activity (proportion of individuals engaging in light or moderate physical activities for 30 minutes a day, during five or more days a week, or intense activity for 20 minutes at least three times a week during their leisure time) and regular fruit and vegetable intake (proportion of individuals consuming fruits and vegetables at least five days a week).

All estimates presented took into account weighing factors that were attributed to each respondent. The final weight of every respondent in each of the 27 cities studied was the result of the multiplication of all three factors. The first factor was the inverse of telephone lines applied in each respondent's household to correct for the likelihood that more than one line was being selected for the sample. The second one was the number of adults in the selected household, which was applied to correct for the likelihood that households with more people would be selected in the sample. Then, the third factor, called poststratification weight, was applied to adjust the sociodemographic characteristics of the sample studied accordingly to those of the entire adult population in the city. 
In order to obtain the poststratification weight, the study sample, after applying the first two mentioned factors, was divided into 36 sociodemographic categories, stratified by gender (male and female), age groups (18-24, 25-34, 35-44, 45-54, 55-64, and 65 years-old and more) and schooling (0-8, 9-11, and 12 years-old and older). The same categorization according to the 2000 Population Census was applied to the sample of adults studied in each city - corresponding to $10 \%$ of all households. The poststratification weight for each sociodemographic category was calculated by dividing the relative rate of the category in the Census sample by the relative rate of the same category in the VIGITEL system.

For making estimates to the entire adult population of the 27 cities studied, the product of the three weighing factors was multiplied by a fourth weighing factor, which took into account the differences related to population in each city. This factor, specific to each city, was the ratio between the number of adults in the city divided by the total number of adults in the 27 cities, based on the 2000 Population Census, and the total number of VIGITEL interviews in the city divided by the total number of VIGITEL interviews in all 27 cities.
Data management and statistical analysis were carried out using STATA software program, version 9, applying the commands that compute proportions with confidence intervals, which take into account weighing factors. Age-adjusted prevalence ratios for trends at different schooling levels were calculated by gender using the Poisson regression with linear models. A 5\% significance level $(\mathrm{p}<0.05)$ and $95 \%$ confidence intervals were set ${ }^{15}$.

\section{Ethical aspects}

Since this study involved telephone interviews, a written free informed consent was not required and a verbal consent was obtained at the time of phone contact with the respondents. The VIGITEL System implementation project has been approved by the Research Ethics Committee of the Brazilian Ministry of Health Human.

\section{Results}

The VIGITEL System conducted 54,251 interviews of which 21,547 with men and 32,704 with women. Men were more likely to report tobacco use, overweight, obesity,

Table 1. Frequencies* $(\%)$ and $95 \%$ confidence intervals $(95 \% \mathrm{Cl})$ of risk and protective factors for chronic non-communicable diseases in adults ( $\geq 18$ years-old), by gender. Brazil, 2007

Tabela 1. Razão de prevalência ajustada por idade dos fatores de risco e proteção para doenças crônicas não-transmissíveis em homens ( $\geq 18$ anos). Brasil, 2007

\begin{tabular}{lcccccc}
\hline \multirow{2}{*}{ Variable } & \multicolumn{2}{c}{ Total } & \multicolumn{2}{c}{ Men } & \multicolumn{2}{c}{ Women } \\
\cline { 2 - 7 } & $\%$ & $(95 \% \mathrm{Cl})$ & $\%$ & $(95 \% \mathrm{Cl})$ & $\%$ & $(95 \% \mathrm{Cl})$ \\
\hline Risk factors & & & & & & \\
$\quad$ Tobacco use & 16.4 & $(15.5-17,3)$ & 20.9 & $(19.4-22.3)$ & 12.6 & $(11.6-13.6)$ \\
$\quad$ Overweight & 43.4 & $(42.3-44.5)$ & 49.2 & $(47.5-50.9)$ & 37.8 & $(36.5-39.1)$ \\
$\quad$ Obesity & 12.9 & $(12.2-13.5)$ & 13.7 & $(12.7-14.8)$ & 12.0 & $(11.2-12.9)$ \\
$\quad$ Sedentary lifestyle & 13.7 & $(13.0-14.4)$ & 15.5 & $(14.4-13.1)$ & 12.2 & $(11.4-13.1)$ \\
$\quad$ Consumption of meat with visible fat & 32.8 & $(31.7-33.8)$ & 42.7 & $(41.0-44.3)$ & 24.3 & $(23.0-25.5)$ \\
$\quad$ Alcohol abuse & 17.5 & $(16.7-18.4)$ & 27.2 & $(25.7-28.7)$ & 9.3 & $(8.4-10.2)$ \\
$\quad$ High-blood pressure & 22.9 & $(22.1-23.7)$ & 20.3 & $(19.1-21.6)$ & 25.1 & $(24.0-26.2)$ \\
$\quad$ Diabetes & 5.3 & $(4.9-5.7)$ & 4.8 & $(4.3-5.4)$ & 5.7 & $(5.2-6.2)$ \\
$\quad$ Dyslipidemia & 15.9 & $(15.3-16.6)$ & 13.3 & $(12.3-14.2)$ & 18.2 & $(17.3-19.0)$ \\
Protection factors & & & & & & \\
$\quad$ Leisure-time physical activity & 15.5 & $(14.8-16.3)$ & 19.3 & $(17.9-20.6)$ & 12.3 & $(11.6-13.0)$ \\
$\quad$ Regular fruit and vegetable intake & 29.4 & $(28.5-30.0)$ & 22.4 & $(21.1-23.6)$ & 35.5 & $(34.3-36.7)$ \\
\hline
\end{tabular}

Source: VIGITEL - surveillance system of risk factors for chronic non-communicable diseases based on computer-assisted telephone interview. *Weighed to represent the distribution of people aged $\geq 18$ years-old, according to the 2000 National Census 
sedentary lifestyle, consumption of meat with visible fat, and alcohol abuse (20.9, $49.2,13.7,15.5,42.7$ and $27.2 \%$, respectively). Reporting rates among women were: $12.6,37.8,12.0,12.2,24.3$ and $9.3 \%$, respectively (Table 1).

Diseases such as high-blood pressure, diabetes and dyslipidemia were more often reported among women than in men (25.1, 5.7 and $18.2 \%$ versus $20.3,4.8$ and $13.3 \%$, respectively) (Table 1).

As for protective factors, men were more active during leisure time (19.3\%) than women (12.3\%). Women showed higher regular fruit and vegetable intake (35.5\%) than men $(22.4 \%)$ (Table 1$)$.

Concerning risk factors in men, the prevalence of tobacco is lower among the ones with more schooling; the age-adjusted prevalence ratio of tobacco use was 0.66 in the highest level of schooling. The same was seen for sedentary lifestyle and highblood pressure; the age-adjusted prevalence ratios were lower in the higher level of schooling and they were 0.97 and 0.80 , respectively, in the highest levels of schooling (Table 2).

The age-adjusted prevalence ratios of overweight, consumption of meat with visible fat, and dyslipidemia (1.22, 1.52, and $1.46 \%$, respectively) were higher in the highest level of schooling.

Obesity, alcohol abuse, and diabetes did not show an association with schooling in men (Table 2).

In regard to protective factors in men, leisure-time, physical activity and regular fruit and vegetable intake were higher

Table 2. Age-adjusted prevalences and prevalence ratios* of risk and protective factors for chronic diseases, according to schooling in men ( $\geq 18$ years-old), Brazil, 2007

Tabela 2. Razão de prevalência ajustada por idade* dos fatores de risco e proteção para doenças crônicas não-transmissíveis em mulheres ( $\geq 18$ anos). Brasil, 2007

\begin{tabular}{|c|c|c|c|c|c|}
\hline \multirow{2}{*}{ Variable } & \multicolumn{4}{|c|}{ Schooling (years) } & \multirow{2}{*}{$\mathrm{p}$} \\
\hline & 0 to 4 & 5 to 8 & 9 to 11 & $\geq 12$ & \\
\hline \multicolumn{6}{|l|}{ Risk factors } \\
\hline \multirow[t]{2}{*}{ Tobacco use } & 1 & 1.20 & 0.74 & 0.66 & $<0.001$ \\
\hline & & $0.97-1.47$ & $0.60-0.91$ & $0.53-0.83$ & \\
\hline \multirow[t]{2}{*}{ Overweight } & 1 & 1.08 & 1.07 & 1.22 & $<0.001$ \\
\hline & & $0.97-1.21$ & $0.96-1.18$ & $1.11-1.35$ & \\
\hline \multirow[t]{2}{*}{ Obesity } & 1 & 1.11 & 1.09 & 1.12 & 0.462 \\
\hline & & $0.87-1.42$ & $0.87-1.38$ & $0.89-1.42$ & \\
\hline \multirow[t]{2}{*}{ Consumption of meat with visible fat } & 1 & 1.10 & 1.12 & 1.52 & $<0.001$ \\
\hline & & $0.93-1.31$ & $0.95-1.31$ & $1.31-1.76$ & \\
\hline \multirow[t]{2}{*}{ Sedentary lifestyle } & 1 & 1.13 & 0.93 & 0.97 & $<0.001$ \\
\hline & & $0.92-1.37$ & $0.77-1.11$ & $0.81-1.16$ & \\
\hline \multirow[t]{2}{*}{ Alcohol abuse } & 1 & 1.44 & 1.29 & 1.32 & 0.251 \\
\hline & & $1.17-1.76$ & $1.06-1.56$ & $1.09-1.61$ & \\
\hline \multirow[t]{2}{*}{ High-blood pressure } & 1 & 0.89 & 0.82 & 0.80 & 0.002 \\
\hline & & $0.77-1.04$ & $0.71-0.95$ & $0.69-0.93$ & \\
\hline \multirow[t]{2}{*}{ Diabetes } & 1 & 0.87 & 1.01 & 0.90 & 0.703 \\
\hline & & $0.65-1.16$ & $0.76-1.34$ & $0.66-1.22$ & \\
\hline \multirow[t]{2}{*}{ Dyslipidemia } & 1 & 1.03 & 1.26 & 1.46 & $<0.001$ \\
\hline & & $0.83-1.28$ & $1.03-1.54$ & $1.20-1.77$ & \\
\hline \multicolumn{6}{|l|}{ Protective factors } \\
\hline \multirow[t]{2}{*}{ Leisure-time physical activity } & 1 & 1.14 & 1.53 & 1.95 & $<0.001$ \\
\hline & & 0.87-1.49 & $1.20-1.94$ & $1.55-2.46$ & \\
\hline \multirow[t]{2}{*}{ Regular fruit and vegetable intake } & 1 & 1.16 & 1.40 & 2.10 & $<0.001$ \\
\hline & & $0.95-1.41$ & $1.18-1.66$ & $1.79-2.47$ & \\
\hline
\end{tabular}

Source: VIGITEL - surveillance system of risk factors for chronic non-communicable diseases based on computer-assisted telephone interview. ${ }^{*}$ weighed to represent the distribution of people aged $\geq 18$ years-old, according to the 2000 National Census; **age-adjusted prevalence ratio. 
among men with more schooling; age-adjusted prevalence ratios were 1.95 and $2.10 \%$, respectively, in those with higher schooling (Table 2).

Amongwomen, tobaccouse, overweight, obesity, high-blood pressure and diabetes were lower among women with more schooling. The age-adjusted prevalence ratios in the highest levels of schooling were $0.66,0.74,0.50,0.56$ and $0.44 \%$, respectively (Table 3 ). Consumption of meat with visible fat and sedentary lifestyle was higher in the highest level of schooling, and the age-adjusted prevalence ratio was 1.67 and $1.51 \%$, respectively (Table 3). Alcohol abuse and dyslipidemia were not associated with schooling (Table 3).

As for protective factors (regular fruit and vegetable intake and leisure-time physical activity) among women, the age-adjusted prevalences were higher among those women with higher schooling; 2.22 and $1.49 \%$, respectively, in those women with the highest levels of schooling (Table 3).

\section{Discussion}

The interviewed sample using VIGITEL in each city was obtained from the entire electronic telephone directory, and thus does not allow any inference about the population without telephone landlines. The coverage of household telephones in the studied cities using VIGITEL was approximately $70 \%$, ranging between $34 \%$ in Macapá (Northern region) and $82 \%$ in Curitiba (Southern region). This means that the coverage rate is lower in less developed

Table 3. Age-adjusted prevalences and prevalence ratios* of risk factors for chronic diseases, according to schooling in women ( $\geq 18$ years-old), Brazil, 2007

Tabela 3. Razão de prevalência ajustada por idade dos fatores de risco e proteção para doenças crônicas não transmissíveis em mulheres ( $\geq 18$ anos). Brasil, 2007

\begin{tabular}{|c|c|c|c|c|c|}
\hline \multirow{2}{*}{ Variable } & \multicolumn{4}{|c|}{ Schooling (years) } & \multirow{2}{*}{$\mathrm{p}$} \\
\hline & 0 to 4 & 5 to 8 & 9 to 11 & $\geq 12$ & \\
\hline \multicolumn{6}{|l|}{ Risk factors } \\
\hline Tobacco use & 1.00 & $\begin{array}{c}0.94 \\
(0.71-1.23)\end{array}$ & $\begin{array}{c}0.66 \\
(0.49-0.89)\end{array}$ & $\begin{array}{c}0.66 \\
(0.50-0.87)\end{array}$ & $<0.001$ \\
\hline Overweight & 1.00 & $\begin{array}{c}1.01 \\
(0.91-1.11)\end{array}$ & $\begin{array}{c}0.82 \\
(0.74-0.90)\end{array}$ & $\begin{array}{c}0.74 \\
(0.67-0.83)\end{array}$ & $<0.001$ \\
\hline Obesity & 1.00 & $\begin{array}{c}0.96 \\
(0.77-1.19)\end{array}$ & $\begin{array}{c}0.70 \\
(0.55-0.88)\end{array}$ & $\begin{array}{c}0.50 \\
(0.40-0.64)\end{array}$ & $<0.001$ \\
\hline Consumption of meat with visible fat & 1.00 & $\begin{array}{c}0.92 \\
(0.79-1.08)\end{array}$ & $\begin{array}{c}1.11 \\
(0.96-1.29)\end{array}$ & $\begin{array}{c}1.67 \\
(1.45-1.93)\end{array}$ & $<0.001$ \\
\hline Sedentary lifestyle & 1.00 & $\begin{array}{c}0.86 \\
(0.69-1.07)\end{array}$ & $\begin{array}{c}1.00 \\
(0.83-1.23)\end{array}$ & $\begin{array}{c}1.51 \\
(1.25-1.82)\end{array}$ & $<0.001$ \\
\hline Alcohol abuse & 1.00 & $\begin{array}{c}1.15 \\
(0.68-1.94)\end{array}$ & $\begin{array}{c}1.07 \\
(0.63-1.82)\end{array}$ & $\begin{array}{c}1.26 \\
(0.76-2.09)\end{array}$ & 0.446 \\
\hline High-blood pressure & 1.00 & $\begin{array}{c}0.92 \\
(0.81-1.04)\end{array}$ & $\begin{array}{c}0.71 \\
(0.61-0.82)\end{array}$ & $\begin{array}{c}0.56 \\
(0.48-0.65)\end{array}$ & $<0.001$ \\
\hline Diabetes $^{1}$ & 1.00 & $\begin{array}{c}0.84 \\
(0.66-1.06)\end{array}$ & $\begin{array}{c}0.72 \\
(0.55-0.93)\end{array}$ & $\begin{array}{c}0.44 \\
(0.31-0.61)\end{array}$ & $<0.001$ \\
\hline Dyslipidemia & 1.00 & $\begin{array}{c}0.97 \\
(0.86-1.10)\end{array}$ & $\begin{array}{c}0.98 \\
(0.88-1.10)\end{array}$ & $\begin{array}{c}1.02 \\
(0.89-1.16)\end{array}$ & 0.849 \\
\hline \multicolumn{6}{|l|}{ Protective factors } \\
\hline Leisure-time physical activity & 1.00 & $\begin{array}{c}1.40 \\
(1.12-1.75)\end{array}$ & $\begin{array}{c}1.82 \\
(1.49-2.23)\end{array}$ & $\begin{array}{c}2.22 \\
(1.80-2.73)\end{array}$ & $<0.001$ \\
\hline Regular fruit and vegetable intake & 1.00 & $\begin{array}{c}0.97 \\
(0.87-1.09)\end{array}$ & $\begin{array}{c}1.12 \\
(1.01-1.25)\end{array}$ & $\begin{array}{c}1.49 \\
(1.35-1.65)\end{array}$ & $<0.001$ \\
\hline
\end{tabular}

Source: VIGITEL - surveillance system of risk factors for chronic non-communicable diseases based on computer-assisted telephone interview. * Weighed to represent the distribution of people aged $\geq 18$ years-old, according to the 2000 National Census; **age-adjusted prevalence ratio 
cities and in lower social strata. In order to reduce differences between the populations studied using VIGITEL and the entire population; we applied weighing factors that partially corrected for the bias resulting from low coverage. Age and education distributions, according to gender, were weighted to represent the Census adult population ${ }^{16}$.

Despite low-coverage of landline telephones, VIGITEL had good performance (response rates between 64.4 and $81.0 \%$ and refusal rates between 5.4 and $15.0 \%$ ), and proved to be a low-cost (around a fifth of that for household surveys) and easy-to-use (reports available in two months) instrument.

Even with coverage limitation, VIGITEL is a useful tool to monitor trends of prevalence and distribution of CNCD risk factors in Brazil.

Compared to the entire population, the studied population using VIGITEL had greater proportion of women and older respondents with higher levels of schooling. However, weighing factors were applied to reduce these differences. The same procedure is applied in the American system, the Behavioral Risk Factor Surveillance System (BRFSS) ${ }^{17}$.

The variable schooling in VIGITEL is a proxy for socioeconomic condition. Several studies in Brazil have shown that schooling is strongly associated with income and health, and improvement of healthcare in children is positively affected by parental education, especially the maternal. The variable schooling contributes to the analysis of life conditions and health situation of the population ${ }^{18,19}$.

Socioeconomic characterization in telephone surveys through schooling constitutes an adequate strategy as it is easily checked through simple questions, with easy answers, and causes little embarrassment to the respondent as it does not go into details about income and possessions, which could be misinterpreted in this approach (through a phone call) ${ }^{8,18}$.

Strong gender differences were found for most risk factors. Tobacco use, overweight, obesity, meat with fat intake, sedentary lifestyle, and alcohol abuse were more frequently seen among men, while highblood pressure, diabetes, and dyslipidemia were more often reported among women. Women more often consume fruits and vegetables and men are more engaged in physical activities during leisure time. The levels of physical activity were higher in both men and women with highest schooling.

Tobacco use, as well as exposure to its smoke, is a major preventable risk factor for $\mathrm{CNCD}^{1}$. According to the 1989 National Health and Nutrition Survey, approximately $40 \%$ of men and $26 \%$ of women aged 15 years-old or older and they were smokers ${ }^{20}$. There was a significant reduction of tobacco use prevalence in the last few decades.

Tobacco use is lower in high schooling population and it could mean greater access to information on its harmful effects. These prevalence differences among higher schooling population have already been described in Brazil ${ }^{20}$.

With respect to alcohol, the VIGITEL survey investigated alcohol abuse, five doses for men and four doses for women at a single occasion. Higher alcohol intake in men is consistent with other studies in Brazil and worldwide $\mathrm{e}^{21-23}$. There was no schooling difference between men and women, which could reflect that alcohol is socially accepted and its consumption is culturally stimulated in all sociocultural and schooling levels.

A study conducted in Southern Brazil also showed higher prevalence of hypertension among respondents with lower education ${ }^{24}$. We found higher prevalence of hypertension and diabetes among women, which may historically reflect in a greater demand of women for health services resulting in a higher proportion of medical diagnoses. Similar findings were also reported in the Third National Health and Nutrition Examination Survey (NHANES III $)^{25}$, in the United States, and in a study in the city of Bambui, in Brazil ${ }^{26}$. The present study may have underestimated the actual prevalence of hypertension because it focused on self-reported medical diagnosis, and characterized a bias of access to health 
services. Yet, higher prevalences of hypertension have been reported in the South and Southeast, the richest Brazilian regions (data was not shown). However, the literature supports that self-reported hypertension is a good indicator for estimating the actual prevalence of this disease, besides being a time- and cost-saving approach ${ }^{25,26}$.

Dyslipidemia is a major risk factor for heart disease. Lower cholesterol and LDL-cholesterol levels have been directly associated with the reduction of some heart conditions, such as acute myocardial infarction and stroke ${ }^{27}$. The present study showed an inverse association in men and a direct association in women between dyslipidemia and education. Women more often reported dyslipidemia than men. However, these findings should be cautiously interpreted since they are based on self-reported medical diagnoses, reflecting in the access to health services. In Brazil, women are more likely to look for health assistance and consequently they presented more dyslipidemia diagnosis than men $^{26}$.

Women were more careful about their diet. They ate more fruits and vegetables than men and consumed less meat with visible fat. The consumption of meat and chicken with visible fat and skin was found in $42.7 \%$ of men and $24.3 \%$ in women, and this finding is consistent with the trend reported in the Family Budget Survey ${ }^{28}$. This habit was seen among men and women with higher schooling, this behavior could be explained by cultural factors as well as access to information.

Research in Brazil, in 2003, has shown that Brazilian young males tend to eat less fruits and vegetables than women ${ }^{29}$. This association between fruit and vegetable intake and gender was also reported in studies of other countries ${ }^{30,31}$.

Some studies have shown that schooling (proxy for income) can contribute to a healthier diet ${ }^{29}$, since more educated people have better access to information and good quality food.

Overweight was lower among women, especially among those more educated. The difference between men and women could be explained by cultural factors: women tend to be more concerned about beauty and weight issues and, thus, they are more careful with their diet, especially among those with higher income (education as a proxy). In contrast, men tend to be more involved with relaxing activities, drinking, and fat appetizers. A study in Canada showed that men with higher income had higher BMI than those with lower income, and an inverse association was seen among women ${ }^{32}$.

Men were more active during leisure time than women, a finding corroborated by other studies in Brazil. These studies have also shown that men more often engage in leisure-time physical activity, especially those with higher schooling ${ }^{33,34}$.

As for sedentary lifestyle, men are more sedentary than women in practically all age groups. This can be explained by the fact that women are the ones doing housework. This finding is corroborated by the 2007 National Household Survey, which found that women are still responsible for housework, even when they are also more involved in out-of-home tasks. Housework, including housecleaning, continues to be a female responsibility, keeping the traditional family structure behavior over the decades $^{35}$. Women with higher schooling do not engage housework.

Another important finding is that people with higher schooling more often engage in leisure-time physical activity, which may reflect unequal access to physical spaces and more availability during leisure time ${ }^{36}$.

Physical activity is a good example of the intersectoriality importance. Having a more active and healthy life depends on the offer and opportunity to have access to spaces for leisure-time physical activities, such as walking paths, cycling tracks, public squares, spaces for sports, in addition to safety, good infrastructure, shaded areas, access by public transportation, among other rights. Thus, the issue of physical activity also involves a discuss on urban planning and mobility taking 
into consideration the way the individuals and the community move, occupy, and create territorial and user's identity with public leisure spaces ${ }^{37}$.

The WHO Commission on Social Determinants of Health recommends monitoring social iniquities in view of supporting social inclusion policies. According to the Commission, to recognize the problem and to be able to measure the magnitude of the iniquity is an essential starting point for action ${ }^{5}$.
In conclusion, gender and schooling play an important role on risk and protective factors for CNCD. Men were more likely to present less favorable situation than women. In general, higher schooling acts as a protective function against CND. VIGITEL is a useful instrument to measure the prevalence of modifiable risk factors and it can contribute to public policy planning as well as surveillance and to identify social inequities, a key issue to be considered in the public policy management.

\section{Referências}

1. WHO. World Health Organization. World Health Report 2002. Reducing risks, promoting healthy life. Geneva: WHO; 2002.

2. Brasil. Ministério da Saúde. Secretaria de Vigilância em Saúde. Departamento de Análise de Situação em Saúde. Saúde Brasil 2006: uma análise da situação de saúde no Brasil. Brasília: Ministério da Saúde; 2006.

3. Malta DC, Cezário AC, Moura L, Morais Neto OL, Silva Jr JB. Construção da vigilância e prevenção das doenças crônicas não trasmissíveis no contexto do sistema único de saúde. Epidem Serv Saud. 2006;15(3):47-64.

4. WHO. World Health Organization. Preventing Cronic Diseases - a vital investment. Geneva: WHO; 2005.

5. WHO. World Health Organization. Subsanar las desigualdades en una generación. Alcançar la equidad sanitaria actuando sobre los determinantes sociales de la salud. Comisión sobre Determinantes Sociales de la Salud I Resumen analític del Inform Final. Geneva: WHO; 2008.

6. Macinko J, Starfield B. Annotated bibliography on equity and health, 1980-2001. Int J Eq Health. 2002;1(1):1-20.

7. Viacava F, Almeida C, Caetano R, Fausto M, Macinko J, Martins M, et al. Uma metodologia de avaliação do desempenho do sistema de saúde brasileiro. Cienc Saúde Col. 2004;9(3):711-24.

8. Brasil. 2008. Ministério da Saúde. VIGITEL Brasil 2007. Vigilância de fatores de risco e proteção para doenças crônicas por inquérito telefônico: estimativas sobre frequência e distribuição sócio-demográfica de fatores de risco e proteção para doenças crônicas nas capitais dos 26 estados brasileiros e no Distrito Federal em 2006. Brasília: Ministério da Saúde; 2008.

9. Moura EC, Morais Neto OL, Malta DC, Moura L, Silva NN, Bernal R, et al. Vigilância de fatores de risco para doenças crônicas por inquérito telefônico nas capitais dos 26 estados brasileiros e no Distrito Federal (2006). Rev Bras Epidemiol. 2008;11 (supl 1):20-37.

10. WHO. World Health Organization. Sample size determination in health studies. A practical manual. Geneva: WHO; 1991.

11. Remington PL, Smith MY, Williamson DF, Anda RF, Gentry EM, Hogelin GC. Design, characteristics, and usefulness of state-based behavioral risk factor surveillance: 1981-87. Public Health Rep. 1988;103(4):366-75.

12. WHO. World Health Organization. Summary: surveillance of risk factors for noncommunicable diseases. The WHO STEP wise approach. Geneva: WHO; 2001.

13. Monteiro CA, Moura EC, Jaime PC, Lucca A, Florindo AA, Figueiredo ICR, et al. Monitoramento de fatores de risco para as doenças crônicas por entrevistas telefônicas. Rev Saúde Pub. 2005;39(1):47-57.

14. WHO. World Health Organization. World Health Report 2002. Reducing risks, promoting healthy life. Geneva: WHO; 2002.

15. Stata Corporation. Stata Statistical Sfotware: Release 9.0. Stata Corporation: College Station, TX; 2005.

16. IBGE. Instituto Brasileiro de Geografia e Estatística. População Padrão Censo de 2000. Rio de Janeiro: IBGE; 2000.

17. CDC. Centers for Disease Control and Prevention. Behavioral Risk Factor Surveillance System - BRFSS. Abouth the BRFSS. Available at http://www.cdc.gov/brfss/ Access on Jun 13, 2011.

18. RIPSA. Rede Interagencial de Informação em Saúde. Indicadores Básicos para a saúde no Brasil: conceitos e aplicações. RIPSA. Organização Pan Americana para a Saúde. 2008. [cited 13 jun 2011]. Available at http://www. ripsa.org.br/fichasIDB/record.php?node=B.2.2\&lang=pt\& version=ed4. 
19. França GN, Gasparine CE, Loureiro PR. Relação entre escolaridade e renda no Brasil na década de 1990. [cited September 2008]. Available at http://www.bnb.gov.br/ content/aplicacao/ETENE/Anais/docs/mesa8_texto3.pdf.

20. Monteiro CA, Cavalcante TM, Moura EC, Claro RM, Szwarcwald CL. Population-based evidence of a strong decline in the prevalence of smokers in Brazil (1989-2003). Bull World Health Org. 2007;85(7):527-34.

21. Barros MBA, Botega NJ, Dalgalarrondo P, Marín-León L, Oliveira HB. Prevalence of alcohol abuse and associated factors in a population-based study. Rev Saúde Pública. 2007;41(4):502-9.

22. Brasil. Ministério da Saúde e Instituto Nacional de Câncer. Inquérito domiciliar sobre comportamentos de risco e morbidade referida de doenças e agravos não transmissíveis: Brasil, 15 capitais e Distrito Federal, 2002-2003. Rio de Janeiro: INCA; 2004.

23. CDC. Centers for Disease Control and Prevention (CDC). Alcohol use among adolescents and adults - New Hampshire, 1991-2003. MMWR Morb Mortal Wkly Rep. 2004;53(8):174-5.

24. Piccini RX, Victora CG. Hipertensão arterial sistêmica em área urbana no sul do Brasil: prevalência e fatores de risco. Rev Saúde Pub. 1994;28(4):261-7.

25. Vargas CM, Burt VL, Gillum RF, Pamuk ER. Validity of self-reported hypertension in the National Health and Nutrition Examination Survey III, 1988-1991. Prev Med. 1997; 6(5):678-85.

26. Lima-Costa MF, Peixoto SV, Firmo JO. A Validade da hipertensão arterial autoreferida e seus determinantes (Projeto Bambuí). Rev Saúde Pub. 2004;38:(5)637-42.

27. Moreira RO, Santos RD, Martinez L. Perfil lipídico de pacientes com alto risco para eventos cardiovasculares na prática clínica diária. Arq Bras Endocrinol Metab. 2006;50(3):481-9.

28. IBGE. Instituto Brasileiro de Geografia e Estatística. Pesquisas de orçamentos familiares 2002-2003: análise da disponibilidade domiciliar de alimentos e do estado nutricional no Brasil. Rio de Janeiro: IBGE; 2004.
29. Jaime PC, Monteiro CA. Fruit and vegetable intake by Brazilian adults, 2003. Cad. Saúde Pública. 2005;21 Suppl:S19-24.

30. Serdula MK, Gillespie C, Kettel-Khan L, Farris R, Seymour J, Denny C. Trends in fruit and vegetable consumption among adults in the United States: behavioral risk factor surveillance system, 1994-2000. Am J Public Health. 2004;94(6):1014-8.

31. Roos G, Johansson L, Kasmel A, Klumbiené J, Prättälä R. Disparities in vegetables and fruit consumption: European cases from the north to the south. Public Health Nut. 2001;4(1):35-43.

32. Matheson FI, Moineddin R, Glazier RH. The weight of place: A multilevel analysis of gender, neighborhood material deprivation, and body mass index among Canadian adults. Soc Sci Med. 2008;66(3):675-90.

33. Monteiro CA, Conde WL, Matsudo SM, Matsudo VR, Bonsenor IM, Lotufo PA. A descriptive epidemiology of leisure-time physical activity in Brazil, 1996-1997. Rev Panam Salud Publica. 2003;14(4):246-54.

34. Hallal PC, Dumith SC, Bastos JP, Reichert FF, Siqueira FV, Azevedo MR. Evolução da pesquisa epidemiológica em atividade física no Brasil: revisão sistemática. Rev Saúde Pública. 2007;41(3):453-60.

35. IBGE. Instituto Brasileiro de Geografia e Estatística. Homem mais escolarizado tem maior participação nas tarefas domésticas. 2008 [cited on 5 Jan 2008]. Available at http://www.ibge.gov.br/home/presidencia/noticias/ noticia_visualiza.php?id_noticia=954\&id_pagina $=1$.

36. He XZ, Baker DW. Differences in leisure-time, household, and work-related physical activity by race, ethnicity, and education. J Gen Intern Med. 2005;20(3):259-66.

37. Seclen-Palacin JA, Jacoby ER. Sociodemographic and environmental factors associated with sports physical activity in the urban population of Peru. Rev Panam Salud Pub. 2003;14(4):255-64.

Recebido em: 05/01/2011 Versão final apresentada em: 13/02/2011 Aprovado em: 25/02/2011 